Article

\title{
Faith-Based Intervention: Prison, Prayer, and Perseverance
}

\author{
Shona Robinson-Edwards ${ }^{1, *(1)}$ and Stephanie Kewley 2 (iD \\ 1 Centre for Applied Criminology, School of Social Sciences, Birmingham City University, The Curzon \\ Building, 4 Cardigan Street, Birmingham B4 7BD, UK \\ 2 School of Natural Science and Psychology, Liverpool John Moores University, James Parsons Building, \\ Byrom Street, Liverpool L3 3AF, UK; S.Kewley@ljmu.ac.uk \\ * Correspondence: shona.robinson-edwards@bcu.ac.uk
}

Received: 18 February 2018; Accepted: 8 April 2018; Published: 16 April 2018

check for updates

\begin{abstract}
This qualitative article explores the impact of faith-based interventions through the lens of a self-identified practicing Christian: Joanna. For over a decade, Joanna has visited several prisons in the United Kingdom in a faith-based capacity: supporting prisoners, families, and prison chaplaincies. Joanna professes the role of faith and religiosity to be a positive and influential component in the lives of those imprisoned. This paper explores Joanna's journey of supporting individuals within the prison walls, reflecting on the impact of labels, imprisonment, faith-based intervention, and religiosity. Much of the current research pertaining to faith-based interventions are limited; therefore, the experiences of those who volunteer within prisons in a faith-based capacity is often overlooked. Yet, faith-based intervention and religiosity within a criminal justice context provides several benefits which impact on those in prison, their families, and people working within a prison environment.
\end{abstract}

Keywords: religiosity; faith-based intervention; support; voluntary work; desistance

\section{Introduction}

Faith-based activities play an integral role within society; therefore, it is critical that faith-based interventions are a key component within the prison regime. This enables those incarcerated to fulfil an active faith-based lifestyle. Indeed, the role of imams, pastors, rabbis, and other faith leaders in prison can provide additional counselling, support, and advice to inmates. Given the harsh conditions of prison, it is perhaps unsurprising that religious conversions within prisons are common and well documented (see Beckford 2012; Easton 2010; Flood 2016; Thornton 2016; Whitehead 2010). High profile criminal cases involving people who experience religious conversion are of particular interest within the media. One case from United Kingdom (UK) involved Karen Matthews, the mother of kidnapped school girl, Shannon Matthews, who reportedly embraced elements of Christianity (Thornton 2016). Karen Matthews played a significant role in her daughter's disappearance which has been described as the "'despicable and inconceivable' kidnap and drugging of her nine-year-old daughter" (Wainwright 2009, p. n/p). Likewise, in the United States (US), O.J Simpson, a former NFL player and convicted armed robber, heavily expressed a faith-based narrative at his 2017 parole hearing (Robinson-Edwards 2017). The rate at which people convert in prison is interesting. It has been reported that prison religious conversion serves as, amongst other things, a coping strategy for those attempting to make sense of their life as well as seeking forgiveness and reparation (Maruna et al. 2006; Schroeder and Frana 2009). Indeed, the phenomenon of faith-based conversion in prison has been explored to a great extent (see Hallett and McCoy 2015; Johnson and Larson 2003). However, an understanding of the role of volunteers within prisons in a faith-based capacity is often overlooked, especially within the context of the UK. 
In the UK the Home Office regularly documents data relating to religion and the prison population. In December 2017, the total prison population in England and Wales stood at 85,494 prisoners, with male prisoners comprising 81,420 of the total prison population (Ministry of Justice 2017). If organized according to religious adherence, $48.5 \%(40,919)$ of the prison population of England and Wales identify as Christian compared to $61.3 \%$ of the general UK population; $15.2 \%(12,825)$ of prisoners identify as Muslim in comparison to $4 \%$ of the general population; $1.8 \%$ (1529) as Buddhist versus $0.5 \%$ of the general population; $0.9 \%$ (759) as Sikh versus $0.7 \%$ of the general population; $0.5 \%$ (400) as Hindu versus $1.5 \%$ of the general population; and $0.5 \%$ (449) as Jewish with a comparable percentage in the general population. $30.5 \%(25,749)$ of the prison population identifies as having no religion; 1.8\% (1547) as "Other", and 0.2\% (130) as "Not Recorded" (Allen and Watson 2017). Although over half the prison population appear to identify with a particular religion, the extent to which that faith is practiced by those who claim to follow it is unclear. Although a religious provision in prison can assist people to continue to practice their faith, arguably, such a context might also assist in helping people to reform and live a life free from crime. Indeed, this research comes at a time when knowledge relating to theories of desistance is growing (Giordano et al. 2008; Glynn 2014; Maruna et al. 2006). Faith-based interventions are thought to play a role in the desistance trajectory as they serve as a 'hook for change' (Giordano et al. 2008), supporting the development and construction of redemptive identities (Maruna et al. 2006) as well as acting as a social support network for those who often are socially isolated (Kewley et al. 2015; Maruna et al. 2006). Faith-based communities and chaplains play an integral part of most western criminal justice systems, allowing prisoners to engage and practice their faith. Indeed, the role of criminal justice practitioners, community leaders, and family members cannot be underestimated in the support process (Weaver 2015). Although significant literature exists on this issue, much of the work is largely drawn from the US (see Armour et al. 2008; Hallett and McCoy 2015; Koenig 1995; Sumter and Clear 1998) and focusses on the prisoner experience. Indeed, little scholarly insight has been dedicated to the experiences of volunteers working in prisons. Given that the role of volunteers within the criminal justice system is vital (see Abrams et al. 2016; Tomczak 2017), further exploration of this issue through the lens of volunteers is needed. Therefore, this paper responds to the need to examine religious activity within the UK from the perspective of those working and volunteering in this environment. This paper outlines the findings of a longitudinal study which explores the experiences of one self-identified practicing Christian: Joanna. The narratives of Joanna were documented and analyzed using narrative analysis. Several narrative identities emerged from this study and this paper focuses on the following six narratives: Mindfulness, Community, Preacher, Counsellor, Forgiveness, and Understanding. This paper concludes with recommendations for policy, practice, and future research.

\subsection{Religiosity, Religion, or Spirituality?}

Religiosity is a complex term, according to VanVleet et al. (1999):

'Religiosity is a term researchers use to quantify an individual's commitment to any particular religion. Although the terms "religion", "religiousness", and "religiosity" are often used interchangeably, many researchers prefer "religiosity" because it denotes a specific measure of individual commitment (like "velocity" as a scientific measure in physics) rather than simply common belief held by a number of people' (VanVleet et al. 1999, p. 3).

Thus, defining religiosity is important. Clayton and Gladden (1974) argue religiosity is one-dimensional; it is "primarily a commitment to an ideology and the other so-called dimensions are merely expressions of the strength of that core commitment" (p. 142). Very few support this view; more readily accepted is the view that religiosity is multi-dimensional (Martos et al. 2010; De Jong et al. 1976; Sedikides and Gebauer 2010). However, the range and description of these dimensions varies (Cornwall et al. 1986). Religiosity literature has explored the relationship and interactions between dimensions as well as other variables; this has inevitably caused significant contradictions in the 
measurement of religiosity (Cornwall et al. 1986). Likewise, research tends to focus upon mainstream religions and traditional world faiths which perhaps appear to lend themselves to easier categorization and measurement. This is often at the expense of 'New Religious Movements' (Wallis 1976) and fundamentalist belief systems. The terms religiosity, religion, and spirituality are frequently used when discussing the role and impact of faith-based interventions. Undoubtedly, people may identify and understand these terms differently. Although there are distinct definitions to these terms, some elements of religion and spirituality embody several similarities. Al Qaradawi (2010) defines religion as "the belief in a divine being, which is worthy of worship and obedience, this is the case when we look at religion from a psychological perspective in terms of religiosity" (Al Qaradawi 2010, p. 2). Spirituality, on the other hand, is described as 'a word that in broad terms stands for lifestyles and practices that embody a vision of human existence and of how the human spirit is to achieve its full potential' (Sheldrake 2012, p. 1).

Glock and Stark (1965) have been influential in developing the understanding of religiosity. Their groundbreaking Religion and Society in Tension (1965), found five dimensions to religiousness including ideological, ritualistic, experiential, intellectual, and consequential. However, it is important to acknowledge some of the challenges which relate to defining the key terms of this study. According to Ronel and Yair (2017), religion usually refers to a social institute of beliefs, knowledge, norms, rules, customs, and rites. They further state that "religion in general, and spirituality both represent human faith in the Supreme and a quest for ultimate meaning" (2017, p. 2). Tart (2012) explores the importance of a non-material realm, structure, set of values, a supportive community, and rituals of spiritual meaning. Abdullah-Johnson (2015) expresses a different perspective, arguing that spirituality and religion are separate concepts, suggesting that spirituality differs from religion. Abdullah-Johnson (2015) suggests that those who identify as spiritual are taught to become aware of the pre-existing relationship one already has with the creator; however, in religion, individuals are taught that you have to find God. Schroeder and Frana (2009) echo Abdullah-Johnson's point to some extent, explaining that religion and spirituality are considered separate concepts, suggesting that careful distinctions must be drawn between the two.

Faith-based interventions are not solely concerned with religious/spiritual labels; in fact, the relationship between religion and spirituality is complex and in need of further clarification (Hill et al. 2000; Jang and Franzen 2013; Schmidt 2011). Therefore, this study does not intend to draw comparison between the two; rather, in this study, religiosity includes corporate religiosity and private spirituality as two dimensions of religiosity (Giordano et al. 2008). Furthermore, this study is not interested in an objective observation of religious behaviors; instead, a subjective lived experience is of interest, allowing a distinctive voice to those engaged in religiosity and spirituality.

\subsection{Faith-Based Intervention in Prison}

Religious or faith-based interventions are not new phenomena. According to Cnaan and Boddie (2002), faith-based social service programs have existed long before the term "faith-based" was coined. Faith-based interventions have been applied across various disciplines and in various sectors ranging from intervention strategies developed by religious organizations (including a potential aim to interlink secular services with faith-infused services) to the legislative requirement for prisons to provide a faith-based framework in prison.

Faith-based organizations within the criminal justice system (CJS) play an increasingly important role. For some, their primary aim is to reduce re-offending; the faith element of their work is secondary. An example of one such organization is Circles of Support. Originally founded by a Christian minister, he gathered support within his local community to work with high risk sexual offenders who were released from custody without statutory restraint or support (Wilson et al. 2005). Similarly, the Mothers' Union, a Christian organization, helps with a wide range of issues which families often face when a member of the community is incarcerated. They offer help with prison visits, provide support for children and parents, run groups for women, and provide safe areas for children to play during 
prison visits. There is no commitment required by beneficiaries to follow the Christian faith; however, members must be baptized and follow the Christian faith (The Mothers Union 2007).

Conversely, there are some faith-based organizations where the practice of faith is a predominant activity; rehabilitation is a positive outcome of engaging with offenders, secondary to the commitment of religious faith and practice. For example, at the InnerChange Freedom Initiative, offenders engage in a structured 16- to 24-month prison programme and a 6- to 12-month community programme which includes life skills, education, housing, employment referrals, mentoring, and developing relationships, along with regular support groups focusing on topics such as substance abuse and victim awareness. These activities are embedded within regular Christian spiritual and religious teachings, religious services, self-exploration, and moral guidance (Johnson and Larson 2003). Likewise, the Kainos Community's Challenge-to-Change programme combines structured cognitive behavioural therapy programmes with life in a therapeutic community. Offenders learn skills and have the opportunity to practice them within this community, receiving feedback from mentors and staff. They are exposed to pro-social interactions and are required to take responsibility for their community (Ellis and Shalev 2008). The fundamental religious preaching of the Kainos Community is Christian. Offenders are not required to be of the Christian faith, but the religious practice and teachings within the Kainos prison wings are overtly Christian (Adler et al. 2008). The Muslim Youth Helpline offers support to young Muslims over the period of Ramadan. The charity aims to ensure that young Muslims in custody are contacted particularly during this festival to prevent feelings of isolation from their wider Muslim community. Gifts, messages of support, and copies of the Quran are sent to young offenders (Aitken 2009). Prison Chaplaincy provides a presence of ministry; they offer support whilst offenders in custody and provide care for inmates whilst balancing the security needs of the prison. Chaplains work with inmates on a humanistic and spiritual level (Thomas and Zaitzow 2006).

Burnside (2008) found "faith-based units in England and Wales found that these units attracted three different types of prisoners, all of whom had different reasons for being there"' (Burnside 2008, p. 3): prisoners who genuinely wanted to change their behavior and saw religious intervention as an opportunity to do so; those who volunteered because they thought it would be an 'easy option'; and religious prisoners who wanted to be in a faith-centered environment. However, this literature is dominated by the examination of the role of faith-based interventions in the reduction of recidivism. Very few look at the role of volunteers. Indeed, in a policy report for reforming prisons and rehabilitating offenders, Aitken (2009) highlighted the significant role and positive impact offenders experience when working with faith-based groups delivered by caring volunteers. He argued their input helped improve offenders' sense of value and self-worth. Therefore, it is critical that we understand the perspectives of volunteers working in this context in order for us to understand how to continue to improve this offering to those incarcerated.

\subsection{Narratives and Story Telling}

Narratives are interpretive devices used by individuals to represent themselves and their worlds (Richardson 1996). Narrative analysis allows a variety of techniques to explore the different ways in which we tell stories those around us whether short stories told in everyday life (Labov 1982), lengthy narratives such as those found in a therapy session (McLeod and Lynch 2000), or interviews about a particular experience (Riessman 1990). Narrative analysis can be complex. As Lawler (2002) explains, narrative perspective sometimes assumes that individuals are able to openly express their thoughts, feelings, attitudes, and values through narratives. In addition, Brookman (2015) argues that narratives can shift between different discourses during interviews; individuals can therefore commit to a different narrative at different times. Indeed, as Carey (2012) argues, "there is no such thing as an unbiased account and stories are likely to be subjective and therefore biased" (Carey 2012, p. 175). We are not detached or "objective observers"' (Yardley et al. 2015, p. 165); instead, we are intertwined within the social world around us. Thus, findings and interpretation of narratives are impacted to some extent and given "meaning by culturally mediated concepts, names and labels" 
(Yardley et al. 2015, p. 165) by the researcher themselves. Rather than fight this potential conflict, narrative analysis allows the researcher to embrace the subjective observation. Looking at narrative identities through oral expression is significant; language enables an exploration in understanding how the storyteller presents stories about their own lives as well as the lives of others. Narrative accounts of individuals who work within the criminal justice system are important to our collective understanding. It is acknowledged that solely using Joanna's narrative account can raise some limitations, as Joanna's subjective perspective is grounded in her personal beliefs and experiences. However, narratives are fundamental in enabling one to make sense of their journey. This study is not meant for generalization; rather, emphasis is placed upon depth rather than breadth.

\section{Materials and Methods}

\subsection{Epistemological Approach}

An interpretivist methodology is utilized, underpinned by a subjective ontology, which acknowledges that people's experiences will be different and therefore warrant unique and individual attention. Such an approach facilitates an understanding of complex, sensitive, and contextual factors. Utilizing a sample size of $N=1$ eradicates the ability to generalize the findings of this study. However, this is not an aim of this study. Rather, the approach is to explore a detailed account of one participant's experiences of volunteering in a faith-based context in prison. This unique role heavily lends itself to the examination of experience through idiosyncratic focus and attention.

\subsubsection{Sample and Sampling}

Joanna is a self-identified Christian. And volunteers within prisons in the UK. She is 64 years old and identifies as Black British. Joanna was recruited through snowball sampling. While attending community meetings, events, and seminars, several people within the faith-based community advised the researcher to contact Joanna with regard to her perspective of faith within prison and the community. Joanna's experience of working within prisons in a faith-based capacity stemmed from a personal encounter. Joanna's son spent time in prison and this was one of the driving forces which influenced Joanna's decision to volunteer within the criminal justice system. Joanna has volunteered in a faith-based context for over a decade and provided an in-depth narrative in relation to faith-based interventions, religiosity, and desistance in prison. Joanna is involved in many community projects which center on rehabilitation, community support, and regularly supporting people whilst they are in prison and following release. Joanna is perhaps also somewhat unique as her voluntary experience is teamed with the experience of supporting her own son who was incarcerated.

\subsubsection{Data Collection}

A total of two interviews were undertaken in a public location agreed upon by both the participant and researcher. Data was collected using semi-structured interviews over a three-month period with each interview lasting 60-90 $\mathrm{min}$. Interviews were digitally recorded and transcribed verbatim. Transcripts were prepared for analysis in the form of listening and re-listening to recordings. This allowed a check of transcripts for accuracy and to ensure elements, such as the tone of voice and pauses, were accurately documented.

\section{The following interview questions provided a guideline during the initial interview.}

1. How long have you volunteered within prisons in a faith-based capacity?

2. In regards to religion, how do you self-identify?

3. What role does religion play in the lives of those imprisoned whom you have come into contact with?

4. What are the benefits of faith-based intervention?

5. What are the challenges of faith-based intervention? 
The second interview captured development and change. The following interview questions provided a guideline.

1. Previously, you described the importance of supporting ex-offenders and families of ex-offenders, are you able to expand?

2. Are you still volunteering within male and female prisons?

3. You described being made to feel welcome by the prisoners, please expand?

4. What role does faith play in your community?

5. In what ways can faith-based initiatives be improved?

\subsubsection{Data Analysis}

Data was analyzed using narrative analysis, an approach similar to content analysis. This enabled the researcher to analyze, develop, and understand the data through the lived experiences of Joanna. The model of narrative analysis utilized was thematic analysis, exploring the content, "what is said more than how it is said" (Riessman [1978] 2007, p. 2). Language is important to our understanding of past events and action (Munhall 2001). Narratives and the stories that people tell are unique; therefore, during the analysis process, it was important for the researchers to be mindful of the context in which the participant existed alongside other temporal and environmental aspects of where the interview took place (Yardley et al. 2015). Analysis is an important part of the research process; however, it is documented that participants occasionally do not reveal an entirely true self but perform a 'preferred self', (Yardley et al. 2015). In some cases, participants tailor how they want to be known by the stories they tell (Goffman 1959; Riessman 2001). The researchers were aware of the above complexities and were mindful of them when analyzing the data.

A thematic approach to narrative analysis was adopted; of interest was the "what" and not the "how" (Riessman 2005). Therefore, analysis relied on the conventional steps of thematic and content analysis. Thus, the following steps were adhered to by the first author, as advised by Joffe (2012). First, the transcript was read and re-read in its entirety. This enabled greater familiarity with the data. Initial ideas were noted down as potential codes and so as not to be lost; this allowed the first author to focus only on the analysis. Following this, a coding frame was developed to guide the analysis. This process used the inductive method, allowing initial codes to emerge from the data. For such a unique case, it was felt that prescribing codes would undermine the subjectivity of the participant's experience. Once an initial coding framework was developed, codes were further developed using theoretically driven inspirations from the research. Definitions of codes and developing themes were noted as well as examples from the data. This ensured the themes stayed close to the participant's words. A strong feature of identity emerged from the data and thus became a main thematic label. The coding frame and data was reviewed by the second author with development of the themes during reflective supervision.

\section{Results}

\subsection{Narrative Identities in Joanna's Story}

Following two in-depth interviews with Joanna, ten narrative identities emerged. Table 1 provides a summary of each. For the purpose of this paper, only six narrative identities will be discussed; these include (1) Mindful Narrative, (2) Community Narrative, (3) Preacher Narrative, (4) Counsellor Narrative, (5) Forgiveness Narrative, and (6) Understanding Narrative. 
Table 1. A summary of the narrative identities highlighted by Joanna.

\begin{tabular}{|c|c|}
\hline Narrative Identities & Summary \\
\hline Community Narrative & $\begin{array}{l}\text { The importance of community is focused on. This narrative explores Joanna's } \\
\text { view relating to the role the community plays in the rehabilitation process for } \\
\text { those in prison and following release. }\end{array}$ \\
\hline Counsellor Narrative & $\begin{array}{l}\text { The counsellor narrative highlights the multifaceted role Joanna plays. Joanna } \\
\text { has frequently counselled, advised, and mentored individuals, both those in } \\
\text { prison and the family members and friends of those behind the prison walls. }\end{array}$ \\
\hline Family Narrative & $\begin{array}{l}\text { The experiences of family members are explored: victimization and secondary } \\
\text { victimization is referred to. }\end{array}$ \\
\hline Forgiveness Narrative & $\begin{array}{l}\text { This narrative draws upon the need for society to 'forgive' and understand the } \\
\text { person who has been convicted of a crime. Joanna's view in relation to } \\
\text { forgiveness, God, and faith is also explored within this narrative. }\end{array}$ \\
\hline Gender Narrative & $\begin{array}{l}\text { The impact of gender in a prison environment is discussed. Additionally, } \\
\text { the implication of a person's offence history and volunteering within a } \\
\text { male-dominated environment is explored. }\end{array}$ \\
\hline Mindful Narrative & $\begin{array}{l}\text { In the mindful narrative, Joanna expresses being mindful of her role in prison. } \\
\text { Aspects such as attire, intentions, and the impact of gender are explored. }\end{array}$ \\
\hline Observant Narrative & $\begin{array}{l}\text { This narrative is concerned with working within prison settings and being aware } \\
\text { of what is taking place within the prison and in the lives of those in prison. }\end{array}$ \\
\hline Personal Narrative & $\begin{array}{l}\text { This narrative highlights Joanna's personal experience of supporting her son } \\
\text { whilst he was in prison. The personal narrative is emotive, drawing on past and } \\
\text { current experiences and how these have impacted Joanna's faith-based } \\
\text { practice today. }\end{array}$ \\
\hline Preacher Narrative & $\begin{array}{l}\text { The preacher narrative draws heavily on Christian beliefs, doctrine, } \\
\text { and scripture. Reference is made to beliefs, forgiveness, the role of God, and the } \\
\text { influential role of faith in the rehabilitation process of those in prison. }\end{array}$ \\
\hline Understanding Narrative & $\begin{array}{l}\text { This narrative expresses an understanding of the impact crime has on the } \\
\text { person in prison and the family members of those incarcerated. }\end{array}$ \\
\hline
\end{tabular}

\subsubsection{Mindful Narrative}

The Mindful Narrative emphasized the importance Joanna places on being mindful of both her presence in prison and those around her. Joanna 'mindfulness' with regards to her position as a volunteer largely concerned her interactions and encounters in male prisons and frequently referred to the impact of various intersectional components. Joanna explored a range of complexities including but not limited to her position as a female practicing Christian and the impact of her identity in largely secular environments. The negative labels attributed to prisoners both within and external to the prison walls as well as the impact of this was at the forefront of Joanna's narrative. Moreover, Joanna was mindful of her femininity and the potential conflicts this had especially in male prison settings. Joanna drew upon this narrative in multiple episodes within the interviews and mindfulness was referred to in a broad context. Joanna's position as a female practicing Christian was at the forefront of all discussions. Joanna was aware that her spiritual journey and the journey of those in prison was not going to be fully understood by wider society; however, she was mindful of the role of faith in her journey expressing, "I believe for me it's my faith ... for me I believe you have to have a calling to go into the prison". Volunteering in prison is complex and Joanna was mindful of the challenges that can arise. Joanna referred to having a calling, with the view that this was not a role for the faint-hearted but one that is rooted in faith, patience, and belief that change is possible even with the most hard to reach in society. The role of gender and age was also recognized; Joanna was aware of the impact this had on communication with those in prisons, "So I got the name they call me mommy, mummy, aunty and I'm thinking oh my goodness". Joanna was mindful of how she was perceived behind the prison walls; many saw Joanna as a mother figure and she was happy that those in prison were able to confide in 
her, "they were able to offload, you know confide and for me that was the onset of my journey in the prison, my role is also as a mother figure I am mindful of this".

The mindful narrative was broad in its nature and was adopted by Joanna on several occasions, making particular reference to the labels which society has placed on those in prison. Joanna was aware of the impact of negative labels on those both in prison and following release. Indeed, her mindfulness allowed her to empathize with people in prison: "I don't like the word prisoner's ... You know we are people who make bad choices". Joanna's narrative emphasized the label 'prisoner' to be detrimental, preferring to draw upon the commonality that we are all human beings, regardless of choices. The mindful narrative not only recognized the negative labels attributed to those in prison but explored the ways in which her faith encouraged to be mindful of an individual's physical and spiritual states, "We have a spiritual life ... because we stray away doing our own thing, we get caught up into the world ( $\sin )^{\prime}$. Therefore, the recognition of personal journeys and life choices was discussed and largely examined from the perspective of religious doctrine. The mindful narrative encompassed a variety of different elements, exploring the importance of being aware of one's environment in prison, one's attire, and the perceptions of people in a prison setting. In terms of to clothing Joanna discussed the responsibility of those going into prison explaining, "You have to be mindful of how you dress ... there men, they are sexual beings ... So we have to be careful how we present ourselves". Joanna was mindful of some of the issues that may have impacted those in prison and suggested that those who work or volunteer in a prison setting should be mindful of these issues. Joanna was not naïve and was aware of the potential for some prisoners to have alternative motives and agendas explaining that "you have to be on you guard, you have to be mindful ... because you know some people have agendas". The mindful narrative was one that Joanna used to express her awareness of the countless issues that arise when volunteering in prison. It is particularly interesting to understand the role of gender, attire, and the impact of negative labels in connection to an exploration of how Joanna's spirituality and faith were always at the forefront of her explanations. This narrative was reflective and future-focused, in that it reflected on past experiences, whilst advising others what they should do in the future.

\subsubsection{Community Narrative}

Within the community narrative, Joanna was an advocate for the importance of the community in the rehabilitation process of people following release. The supportive role Joanna played in her community was key to this narrative and one she appeared to encourage others to adopt. Her community narrative was particularly drawn from the importance she places on the role of faith-based communities in the rehabilitation of ex-offenders. Joanna described faith-based support within prison but simulatenously the lack of this care and support for those who have been released, "for me it's when they come out-you know because of how society negatively thinks it sends them (ex-offenders) backwards instead of forward". Her overarching position was that the community at large must rethink its position on those in the criminal justice system; they must "renew there thinking to give people a chance and an opportunity". Her narrative presented a view that people ought to look at those in prison as human beings, not just people who have committed offences. Joanna's community narrative determined not only the type of action communities must take but she also provided a solution as to how to achieve this, that communities must "retrain there thinking". This was important to Joanna as it was her "passion, my heart beat is the community, we need to train, re train". Further expressing that the treatment of ex-offenders should be grounded in love, she insisted "you should not reject them and abandon them but to love them, to embrace them, to help them". The community narrative was an interesting one for Joanna. On the one hand, she noted how society was responsible for the labels it attributes to people, as she states "because of how society thinks it sends them backwards instead of forward". Joanna also argued that the community should play a role in providing a support system to the families of those in prison as they "also need to be supported, because there going through their time in prison as well". Joanna viewed imprisonment, offending, reoffending, faith, and rehabilitation as a community issue, not an individual one. Indeed, throughout the interview, Joanna explored the aspect of the wider social structures which 
she believed needed to play a key role, "I believe the Government should play a bigger role, they're not playing enough of a part". This community narrative was one that Joanna used to express her beliefs about both her role as well as that of others in society when working with people in the criminal justice system. It is interesting to note that her concern extended beyond the person incarcerated but included both the inmate's family as well as society itself.

\subsubsection{Preacher Narrative}

The preacher narrative drew heavily on Joanna's Christian beliefs with reference to Christian doctrine and scripture. Belief, religion, forgiveness, and the role of God was central to this narrative. Joanna recognized that her religious views would not be understood by everyone; however, she was a strong advocate for her religious views. Joanna referred to the time when she became a practicing Christian, referring to this as "coming to the Lord". Joanna's religious position was discussed throughout the interview and emphasis was placed on the role of God in the lives of those in prison. Joanna also expressed her personal journey to the Christian faith, "I came to the Lord at later life, I was nearly fifty". This was an important point as Joanna went to suggest that she believe there is not a set age or a set place associated with religious conversion, further stating, "There are many people in prison who have also acknowledged God at a later stage in life we have a understanding". The preacher narrative was an important one to Joanna and one that Joanna used to discuss her religious beliefs. Joanna clearly recognized that there are people in prison who openly practice other forms of religion, "There are also Muslim prisoners I speak to everyone no matter the background".

The role of God in the lives of those in prison was frequently discussed. Additionally, Joanna's clear position in this narrative was to promote the role of God both in her life and the lives of those in prison. The preacher narrative enabled Joanna to openly speak about God, exploring the perception and the importance of God. This narrative explored Joanna's ability to openly discuss God, not just within religious circles but also within the criminal justice system. This narrative was centered on Joanna's perception of the role of God in prison, "God always comes into the conversation, because he is allowed to, a lot of people in prison they turn to God". Joanna described the ability to openly discuss God and the consequences of faith-based intervention in prison, "Some get saved, get baptized and they hold on to their religion, they hold on to their belief" Joanna's perception of God is important. Through her speech, Joanna attempts to teach others about her belief system and the impact it has on those with whom she works.

There was frequent reference to the Word of God and the importance of not judging people especially those in prison, "We don't judge, we read the Bible, read the word of God and teach and discuss". Joanna believes that working in a faith-based capacity within prisons is challenging; however, she often explained that judgement should only come from God. The preacher narrative was one that Joanna used to portray her views on forgiveness and the importance of the Bible. Joanna believes that religion plays an influential role in the lives of some individuals who are in prison, "If we believe in what the word of God says we cannot judge, God is the Judge". Further, this narrative was used by Joanna to emphasize her position, "I'm not going into prisons in vain, I'm helping people, religion and faith are important to them and me". Joanna's focus relates to teaching and supporting those in prison in a faith-based capacity, those who show an interest in learning more about religion.

\subsubsection{Counsellor Narrative}

The counsellor narrative expressed the multifaceted role Joanna has undertaken. Joanna believes there is a general assumption that volunteering in prison in a faith-based capacity solely involves partaking in Sunday services. Joanna strongly dismissed this. Joanna described her role both in a faith-based context and beyond, discussing that religion was not a new feature for those whom she had come into contact with. Rather, many had acknowledged religion and God, "When I go in and I counsel them the reality is the majority of them have been to church, they know about God". Joanna provided an insight into religion behind bars, suggesting that the role of religion in the lives of those 
in prisons was not a new concept, "The benefits and role of religion in prison is not new, people in prison have a connection to faith in a lot of ways". Many of those whom Joanna had come into contact with had previous experiences of religion; for example, attending churches and various religious places of worship prior to imprisonment. Joanna also explored the impact of counselling those in prison who hah severe mental health challenges. Additionally, the counsellor narrative highlights the role of counselling prisoners and the family of prisoners in a faith-based capacity, "he (prisoner) had some mental health issues ... he was suicidal I took about a year to get through to him". Joanna recognized the severity of working in a prison environment with people who are sometimes deemed vulnerable. The importance of a prisoner's and their family's wellbeing was key; Joanna expressed some disappointment in regards to the lack of support for those in need. Joanna emphasized her role in counselling and supporting the families of those in prison, "I get a lot of calls from family members and I listen to their problems, I'm happy to help". Joanna used the counsellor narrative to express the complex nature of volunteering within prisons; this narrative highlighted the challenges Joanna had experienced with regards to counselling those in prison. Joanna's counselling role was described as an unofficial role but one that was an integral part of her time in prison. Joanna has dealt with complex situations and has had to manage things accordingly. In some cases, Joanna expressed the impact of counselling people which had led her to blame herself when things went wrong, "he was on suicide watch, we were there with him and he talked to, after I came home we found out he took his own life". This was a difficult time for Joanna; Joanna shared that she prayed with the prisoner, "I asked the question would you like me to pray and I prayed with him". She added to this, further expressing, "Maybe I could have done more, this was hard for me because I spoke to him on the very day he took his own life". Although many low emotional moments were shared in this narrative, Joanna also used this narrative to express the multifaceted role of volunteering in prison. The focus was not solely on those in prison but also on the families of prisoners. It is clear that, albeit an unofficial role, the qualities of a counsellor played a vital role in Joanna's experience.

\subsubsection{Forgiveness Narrative}

The forgiveness narrative was one that was constantly referred to throughout Joanna's narratives. Joanna expressed a belief that we are all sinners; however, she acknowledged the importance of religion and the role it plays in changing the lives of individuals. This narrative expressed that the acknowledgment of God, alongside the recognition of religious principles, can lead individuals to a life free from crime. Forgiveness was a central feature of this narrative, "there is a God and we are all sinners, what makes us do things right is turning our life to the lord". The forgiveness narrative drew on Joanna's view that all human beings sometimes make mistakes, further suggesting that God is able to forgive people, irrespective of their crimes. Within this narrative, there was an acknowledgement of the impact of criminality and personal choice; however, the concept of a second chance, redemption, and forgiveness was also expressed. The forgiveness narrative was heavily influenced by Joanna's faith along with her personal and moral beliefs. This narrative frequently referred to biblical sayings to support and illustrate points, "if we see it from a Godly perspective God loves sinners, he just doesn't love the sin". Emphasis was placed on the need for forgiveness; Joanna expressed a hope that people would be able to see the person beyond the crimes they had committed, distinguishing between the person and the crime. This narrative drew on the concept that people and society need to be more forgiving, suggesting that this would positively impact the rehabilitation process for individuals following release. Joanna used this narrative to highlight the need to refrain from judging or rejecting both those who are in prison and those who have been released. There was a heavy influence on the importance of care, love, and support for ex-offenders. Joanna expressed the importance of not judging people who are in prison, "we judge people don't we, and going into that environment you cannot judge people". Joanna further stated, "We should not reject them and abandon them but love them, embrace them, and help them". This narrative mae reference to God's love for the sinner; Joanna attempted to highlight the similarities between all people, whether in prison or not. Joanna argued that we all have made 
mistakes in our lives. Interestingly, this narrative tended to overlap with the views expressed in the understanding and preacher narratives.

\subsubsection{Understanding Narrative}

Joanna used the understanding narrative to describe the importance of understanding the offender's/ex-offender's journey and motives for criminality, "We have to understand the person behind the offence". In this narrative, Joanna wanted people to view those in prison as human beings rather than hardened criminals. Additionally, Joanna used this narrative to educate and inform people of the experiences many offenders/ex-offenders face, "We should know the challenges they face before prison and after prison, we should know their experiences it's very hard for some of them". This narrative portrayed understanding, compassion, support, and care. Joanna's personal experience of visiting inmates' family members fostered in-depth empathy for the inmate as well as the inmate's family, "my first experience it was awful ... my son went to prison, so that was my experience. It was horrendous it was heart wrenching". The understanding narrative was also based on personal experiences; Joanna made several references to her son's experience in prison and her ability to understand the experiences of others. Notably, Joanna consistently referred to understanding the experiences of prisoners and their families, "I had to gain all these experiences so that when I go into the prison I had a understanding, a deep understanding of what's it's like for the offenders and for the families". She suggested that volunteering at the prison in addition to her personal experience of dealing with an incarcerated family member allowed Joanna an in-depth and compassionate understanding surrounding the issue, "I've got to help people, not just the offenders but families", further stating "I can embrace them you know, the visitors come and visit I can go with them". Joanna used the understanding narrative to highlight the breadth of her understanding, one which included but was not limited to speaking, counselling, and assisting prisoners and the families of those in prison. These narratives identified key elements in Joanna's story and presented the complex nature of volunteering within prisons in the UK. These narratives explored topics relating to Joanna's personal experiences, the experiences of those in prison, and the impact of imprisonment on the family of those in prison.

\section{Discussion}

The unique findings of this research are key to the development of further knowledge in understanding the experiences of people who volunteer in the prison service within a faith-based capacity. The discussion surrounding rehabilitation, desistance, and faith has begun to attract greater attention; accordingly, these findings are crucial in understanding the role of volunteers in this context. It is important to acknowledge the context of culture as it relates to this topic; significant research pertaining to faith, prisons, and rehabilitation stems from the US criminal justice system. However, our findings highlight that, although faith-based work is not a prominent feature in criminological academic research in the UK, it is one that has a profound impact on the lives of some individuals (Aitken 2009). This paper explored the role of faith-based interventions and religiosity in prison from the perspective of Joanna, a faith-based volunteer. This was done by focusing on the narrative accounts of one individual, Joanna. A total of ten narrative identities emerged, of which six were presented here. Although the Mindfulness, Community, Preacher, Counsellor, Forgiveness, and Understanding narratives were discussed separately, several of the narratives exhibited similarities and overlapped in significant areas.

The six narratives highlighted suggest that there are several elements that are foundational to Joanna's role as a faith-based volunteer. The mindful narrative was broad in nature and demonstrated that Joanna had to be mindful of her presence in prison and those around her. Joanna was not solely focused on going into prisons and speaking to those in need; however, other factors of working in prison were constantly at the forefront of Joanna's mind. Mindfulness also contextualized Joanna's acknowledgement of the crucial elements of intersectionality (Crenshaw 1995). Joanna recognized that her gender, religion, and age were 'enabling factors'; for example, as mid-60-year-old woman, 
Joanna saw herself as an approachable figure, often likened to a mother figure by those with whom she worked. Arguably, if Joanna had been in her mid-30's, the interaction between her and those in prison may have been significantly different. Faith was another enabling factor: Joanna's Christian beliefs fostered a means by which she had the opportunity to support those in prison who followed a similar belief system. This similarity enabled the facilitation of providing support and services within prison and beyond. In contrast, gender may have been partially an enabling factor, contributive towards Joanna's role as a mother figure; however, it may also have been disabling in that the offences of those in prison are often heavily gendered. Therefore, for those who have particular issues with women, Joanna's gender could potentially be perceived as a disabling factor. Gender roles and gender norms seem to have been an influential factor (Wolbrecht et al. 2008); a women's stereotypical role of as a care giver, a good listener, and compassionate were perpetuated in this narrative. Having said this, this characteristic did not seem to be centered on Joanna's gender. Joanna's faith was the influential reasoning behind her actions. Lastly, the mindfulness narrative was heavily concerned with society's role in the rehabilitation and desistance process of ex-offenders. Joanna was mindful of the impact of negative labels and stigmatization (Becker 1966); she was also mindful of the impact of labels and stigma on those in prison and their life following release. Joanna is a strong advocate for those in prison and the Good Lives Model of offender rehabilitation appears to fit in this context (Ward 2002; Ward and Maruna 2007). Essentially, Joanna expressed the belief that people should be given a chance. Similarly, the good lives model argues that giving individuals opportunities to achieve in socially acceptable and meaningful ways is important. Therefore, understanding does not solely have to come from politicians and those who work within the criminal justice system. The wider society has to be aware of how labels, stereotypes, and stigma can impact individuals, especially those who are incarcerated.

Although both the mindfulness and community narrative had unique respective points, they also complemented one another with regard to what Joanna sought to express. The sense of community and team work in relation to rehabilitation was a key feature in both narratives. Although Joanna argued that we should be mindful of several things when encountering individuals enmeshed in the prison system, she further argued that communities needed to be more proactive in the rehabilitation process of individuals. Joanna expressed that there was a range of faith-based support in prison; however, a lack of support for those following release. This was a concern as religiosity, desistance, and rehabilitation are processes. Although some in prison benefit from support whilst they are imprisoned, this also needs to be echoed following their release. Although Joanna did call for the help of the government in this area, her focus was on the community to play an active role. According to Joanna, a discussion about faith-based work is needed before positive renewed thinking about the prison system, punishment, and rehabilitation can be accomplished. Rhetoric surrounding the presence and role of religion in prison recently has not been entirely positive in the UK media. In order for communities to become involved, they must be brought into the discussion. Additionally, the UK is a multicultural country with individuals from many different faith backgrounds. There needs to be some acknowledgement that the community can play a role in supporting ex-offenders following their release from prison, irrespective of one's religious views. For example, Joanna frequently expressed speaking to individuals from many different backgrounds. Although religion played an influential part in her process, the other roles Joanna undertook, whether as listener, counsellor, or mentor, were also appealing characteristics to those who are in prison and those post release.

The counsellor narrative showed that Joanna had taken on various roles within her work with prisoners. Although religiosity was an enabling factor in terms of her access to the prison system, clearly this was not the only appealing feature. Joanna's counselling narrative demonstrated that she provided support to those in prison and the family of those in prison. Although the families of those in prison may not have been directly concerned with the religious aspect of Joanna's role, she communicated how the families were appreciative of her time, support, and encouragement. Joanna's time in prisons had seen her take on several roles; this was something that was demonstrated across the narratives 
discussed. Counselling and mentoring were frequent roles that Joanna undertook. Mentoring has several benefits; as a mentor, Joanna could be effective in providing informal and emotional support (Devilly et al. 2005) whilst promoting adherence to formal interventions (Jucovy 2006). Clearly, the voluntary sector has and continues to provide a substantial amount of support to the criminal justice system. It is easy to assume that faith-based intervention only involves, for example, Friday Jumm'ah services for Muslim prisoners; Saturday or Sunday services for Christian prisoners; or Bible study or other faith-based classes that take place in the week. However, this intervention is much more complex than what meets the eye. Those who work or volunteer within prisons will hear traumatic stories and deal with individuals who may be deemed as 'hard to reach' or vulnerable. Joanna talked about an occasion in which she spoke to a suicidal prisoner, learning afterwards that the prison had shortly thereafter taken his own life. Those who volunteer within prison face severe and life-changing experiences. The counsellor narrative captured this; however, it is also important to recognize the potential impact this can have on volunteers like Joanna. Self-blame and wanting to do more are only two examples of this emotional impact; however, the clear positive factor in Joanna's love and passion for this role is her faith and religious views.

The preacher narrative centered on Joanna's Christian beliefs, irrespective of the challenges and complexities of volunteering within prisons. Joanna's belief system was a constant driving force. Joanna expressed her confidence that Christianity can help some people in prison; however, she was also aware that other religions may serve as a similar support to others with different beliefs. Statistically, non-Christian religious groups are currently growing in the UK prison population (Allen and Watson 2017), showing a need for a multi faith perspective within the criminal justice system. Volunteering in prison in a faith-based capacity enables an open discussion surrounding religion, one which this study has shown to be a benefit to both those in prison and the volunteers who dedicate their time there, i.e., Joanna. There are numerous debates regarding the secularization of the UK; for example, the controversial decision to ban a Church of England cinema advertisement featuring the Lord's Prayer has been discussed in both political and media arenas (Pulver 2015). In a democratic society, peaceful religious speech should not be banned from public spaces (Fraser 2015); however, the role of religion and religiosity continues to spark debate in the UK. The debate about religious freedoms and the extent to which religious views are acceptable is a topic of continuous discussion. In contrast, Joanna expressed that she felt refreshed in her ability to openly discuss religion, faith, and forgiveness within her volunteering role not to mention her ability to provide a safe space in prison for those who also seek to express their religious views and practice their religion. Lastly, the understanding and forgiveness narrative went hand in hand. Joanna expressed a need to first understand the reasoning behind a person's offences, followed by a need to forgive individuals. Rehabilitating and reintegrating individuals back into society is thought to be a consequence of understanding and forgiveness. Joanna's perspective was grounded in her faith where forgiveness is a central component. However, those who may have been the victims of a crime or those who do not necessarily hold the same religious views as Joanna may not agree with this concept. Joanna was aware that her religious views and broader beliefs regarding crime and punishment were built upon the principles of her faith, a belief system that some will not understand or adhere to. However, Joanna's experiences have highlighted that volunteering within prisons is not simplistic; it is challenging, emotive, and constantly changing. Regardless of what religion an individual follows, faith-based intervention can play a vital part in the lives of those in prison or post release (see Robinson-Edwards and Pinkney 2018). In some cases, prisoners may not be particularly religious; however, the support received from Joanna and other volunteers in prison can be vital. Joanna illustrated the impact volunteering in prisons had on her personally; however, the overarching factor was Joanna's experience of seeing the benefit of religiosity in prison.

\section{Conclusions}

This paper has explored the narrative identities highlighted by Joanna. We acknowledge that this study cannot be generalized to larger populations; instead, its purpose was to engage in an exploration 
of the context in which Joanna worked (McAdams 2012; Yardley et al. 2015) and conclude with the following points. First, we intend for this study to contribute to the criminological knowledge of faith-based interventions while also contributing to a pathway of research exploring current issues impacting rehabilitation, desistance, and religiosity for those in prison and post release. Second, we suggest that the narrative identities highlighted should be utilized by those working with volunteers to understand the complex nature of volunteering within prison in a faith-based context. Understanding such complexities will assist prisons, faith communities, and third sector agencies to appreciate the needs and interests of their volunteers. Such an understanding will support the recruitment, training, and supervision needs of volunteers. Third, we echo the need for policy makers, researchers, and prison practitioners to appreciate that engaging in a process of desistance and rehabilitation is a journey. Doing this through a religious pathway is not different. Fourth, further research is needed to explore the narratives of larger samples of volunteers; of interest would be to understand differences or similarities in volunteer gender, religion, varying prison population communities, and length of experience. Likewise, the experiences of faith-based volunteers within a wider criminal justice context should be explored, as prison is only one aspect of the journey and very little is documented on the experience of volunteers within the criminal justice system. Such research is important to our collective understanding surrounding the experience of volunteering, faith, and religiosity in prison.

Acknowledgments: A special thanks goes to Joanna for openly expressing her experiences of religion and faith based intervention in a criminal justice context. Thanks also to Religions interdisciplinary open access journal and Guest Editor Professor Kent R. Kerley for the timely collection of work within this special edition.

Author Contributions: Shona Robinson-Edwards conducted the participant research interviews; Shona Robinson-Edwards analyzed the data; Stephanie Kewley advised and contributed to the analysis tools; Shona Robinson-Edwards wrote the paper and made revisions.

Conflicts of Interest: The authors declare no conflict of interest.

\section{References}

Abdullah-Johnson, Umar. 2015. The Truth about Black Religion and Spirituality and the Lies of Christianity, Islam. Available online: https:/ / www.youtube.com/watch?v=9oei8UOQb2w (accessed on 19 October 2015).

Abrams, Laura, Emma Hughes, Michelle Inderbitzin, and Rosie Meek. 2016. The Voluntary Sector in Prisons Encouraging Personal and Institutional Change. New York: Palgrave Macmillan US.

Adler, Joanna R., Jonathan Burnside, Nancy Loucks, and Tendayi Viki. 2008. Measuring religion in prisons: Offenders' beliefs and attitudes. Journal of Forensic Psychology Practice 8: 130-49. [CrossRef]

Aitken, Jonathan. 2009. Breakthrough Britain: Locked up potential. In A Strategy for Reforming Prisons and Rehabilitating Prisoners. London: Centre for Social Justice, Available online: http://www. centreforsocialjustice.org.uk/client/downloads/CSJLockedUpPotentialFULLrEPORT.pdf (accessed on 10 December 2017).

Al Qaradawi, Yusuf. 2010. Islam and Introduction. Petaling Jaya: Islamic Book Trust Malaysia.

Allen, Grahame, and Chris Watson. 2017. Prison Population Statistics. Briefing Paper Number SN/SG/04334, 4 July 2016. Available online: http://researchbriefings.files.parliament.uk/documents/SN04334/SN04334.pdf (accessed on 27 February 2017).

Armour, Peterson, Windsor Marilyn, Liliane Cambraia, Jemel Aguilar, and Crystal Taub. 2008. A Pilot Study of a Faith-based Restorative Justice Intervention for Christian and Non-Christian Offenders. Journal of Psychology \& Christianity 27: 159-67.

Becker, Howard S. 1966. Outsiders, Studies in the Sociology of Deviance. New York: The Free Press.

Beckford, Martin. 2012. Prisoners under Pressure to Convert to Muslim 'Gang'. Available online: http://www.telegraph.co.uk/news/uknews/law-and-order/9298578/Prisoners-under-pressure-toconvert-to-Muslim-gang.html (accessed on 6 March 2017).

Brookman, Fiona. 2015. The Shifting Narratives of Violent Offender. In Narrative Criminology: Understanding Stories of Crime. Edited by Lois Presser and Sveinung Sandberg. New York: New York University Press, pp. 209-11. 
Burnside, Johnathan. 2008. From England, Religious Interventions in Prison. Available online: http:/ / seekjustice.co. uk/MyBrothersKeeperDownloads/religion_prisons_Kairos_APAC_Kainos.pdf (accessed on 9 December 2017).

Carey, Malcom. 2012. Qualitative Research Skills for Social Work: Theory and Practice. Farnham: Ashgate Publishing Limited.

Clayton, Richard R., and James W. Gladden. 1974. The five dimensions of religiosity: Toward demythologizing a sacred artifact. Journal for the Scientific Study of Religion 13: 135-43. [CrossRef]

Cnaan, Ram, and Stephanie Boddie. 2002. Charitable-Choice and Faith-Based Welfare: A Call for Social Work. Social Work 47: 224-35. [CrossRef] [PubMed]

Cornwall, Marie, Stan L. Albrecht, Perry H. Cunningham, and Brian L. Pitcher. 1986. The dimensions of religiosity: A conceptual model with an empirical test. Review of Religious Research 27: 226-44. [CrossRef]

Crenshaw, Kimberlé. 1995. Critical Race Theory: The Key Writings that Formed the Movement. New York: The New Press.

De Jong, Gordon F., Joseph E. Faulkner, and Rex H. Warland. 1976. Dimensions of religiosity reconsidered; Evidence from a cross-cultural study. Social Forces 54: 866-89. [CrossRef]

Devilly, Grant, Laura Sorbellp, Lynne Eccleston, and Tony Ward. 2005. Peer-Based Education Schemes. Aggression and Violent Behaviours 10: 219-40. [CrossRef]

Easton, Mark. 2010. Islam Prison Conversions. Available online: http://www.bbc.co.uk/blogs/thereporters / markeaston/2010/06/islam_prison_1.html (accessed on 6 March 2017).

Ellis, Tom, and Karen Shalev. 2008. An Evaluation of the Effectiveness of the Kainos Community 'Challenge-to-Change' Programme in English Prisons: University of Portsmouth: Institute of Criminal Justice Studies. Available online: http:/ / www.kainoscommunity.com/FINAL\%20PORTSMOUTH\%20REPORT\% 2024\%20weeks.pdf (accessed on 10 January 2017).

Flood, Rebecca. 2016. Yorkshire Ripper Turns to Islam after Muslim Gangs Offer Mass Murderer Jail Protection. Available online: http:/ /www.express.co.uk/news/uk/707126/yorkshire-ripper-islam-muslim-convertprison-peter-sutcliffe (accessed on 4 April 2017).

Fraser, Giles. 2015. Banning the Lord Prayer. The Guardian. Available online: http://www.theguardian. com/commentisfree/2015/nov/22/banning-lords-prayer-cinema-star-wars-christianity (accessed on 18 February 2018).

Giordano, Peggy, Monica Longmore, Ryan Schroeder, and Patrick Seffrin. 2008. A Life-Course Perspective on Spirituality and Desistance from Crime. Criminology 46: 99-132. [CrossRef]

Glock, Charles, and Rodney Stark. 1965. Religion and Society in Tension. San Francisco: Rand McNally.

Glynn, Martin. 2014. Black Men, Invisibility, and Crime: Towards a Critical Race Theory of Desistance. London: Routledge.

Goffman, Erving. 1959. The Presentation of Self in Everyday Life. New York: Doubleday.

Hallett, Michael, and Stephen J. McCoy. 2015. Religiously Motivated Desistance: An Exploratory Study. International Journal of Offender Therapy and Comparative Criminology 59: 855-72. [CrossRef] [PubMed]

Hill, Peter C., Kenneth Pargament II, Ralph W. Hood Jr., Michael E. McCullough, James P. Swyers, David B. Larson, and Brian J. Zinnbauer. 2000. Conceptualizing Religion and Spirituality: Points of Commonality, Points of Departure. Journal for the Study of Social Behavior 30: 51-77. [CrossRef]

Jang, Sung Joon, and Aaron Franzen. 2013. Is Being "Spiritual" Enough Without Being Religious? A Study of Violent and Property Crimes among Emerging Adults. Criminology 51: 595-626. [CrossRef]

Joffe, H. 2012. Thematic analysis. In Qualitative Research Methods in Mental Health and Psychotherapy: A Guide for Students and Practitioners. Edited by David Harper and Andrew R. Thompson. Chichester: Wiley-Blackwell, pp. 209-23.

Johnson, Byronand, and David Larson. 2003. The InnerChange Freedom Initiative: A Preliminary Evaluation of a Faith-Based Prison Program. Philadelphia: Center for Research on Religion and Urban Civil Society, University of Pennsylvania.

Jucovy, Linda. 2006. Just Out: Early Lessons from the Ready4Work Prisoner Reentry Initiative. Baltimore: Annie E. Casey Foundation.

Kewley, Stephanie, Anthony Beech, and Leigh Harkin. 2015. Examining the Role of Faith Community Groups with Sexual Offenders: A systematic review, Aggression and Violent Behavior. Available online: http: / / dx.doi.org/10.1016/j.avb.2015.07.016 (accessed on 1 March 2017). 
Koenig, Harold. 1995. Religion and Older Men in Prison. International Journal of Geriatric Psychology 10: 219-30. [CrossRef]

Labov, William. 1982. Speech Actions and Reactions in Personal Narrative. In He-Said-She-Said. Talk as Social Organization among Black Children. Edited by Marjorie Harness Goodwin. Bloomington: Indiana University Press.

Lawler, Stephanie. 2002. Narratives in Social Research. In May, Tim. Qualitative Research in Action. London: Sage. Martos, Tamás, Barna Konkolÿ Thege, and Michael F. Steger. 2010. It's not only what you hold, it's how you hold it: Dimensions of religiosity and meaning in life. Personality and Individual Differences 49: 863-68. [CrossRef]

Maruna, Shadd, Louise Wilson, and Kathryn Curran. 2006. Why God Is Often Found Behind Bars: Prison Conversions and the Crisis of Self-Narrative. Research in Huma Development 3: 161-84.

McAdams, Dan. 2012. Exploring Psychological Themes through Life Narrative Accounts. In Varieties of Narrative Analysis. Edited by James Holstien and Jaber Gubriam. Thousand Oaks: SAGE, pp. 15-32.

McLeod, John, and Gordon Lynch. 2000. This is our life: Strong Evaluation in Psychotherapy Narrative. European Journal of Psychotherapy, Counselling and Health 3: 389-407. [CrossRef]

Ministry of Justice. 2017. Prison Population Figures. Available online: https://www.gov.uk/government/ statistics / prison-population-figures-2017 (accessed on 17 October 2017).

Munhall, Patricia. 2001. Nursing Research a Qualitative Perspective. London: Jones \& Bartlett.

Pulver, Andrew. 2015. The Lord's Prayer Row: Can Cinemas Really Ban Adverts? The Guardian. Available online: https: / / www.theguardian.com/film/filmblog/2015/nov/24/lords-prayer-row-can-cinemas-reallyban-adverts-church-of-england-dcm (accessed on 18 February 2018).

Richardson, John, ed. 1996. Handbook of Qualitative Research Methods for Psychology and the Social Sciences. Leicester: BPS Books.

Riessman, Catherine Kohler. 2007. Narrative Analysis. In The Sage Encyclopedia of Social Science Research Methods. Edited by Michael Lewis-Beck, Alan Bryman and Tim Futing Liao. Thousand Oaks: Sage, 3 Vol. boxed set. First published 2003.

Riessman, Catherine Kohler. 1990. Divorce Talk: Women and Men Make Sense of Personal Relationships. New Brunswick: Rutgers University Press.

Riessman, Catherine Kohler. 2001. Narrative Methods for the Human Sciences. Thousand Oaks: SAGE.

Riessman, Catherine Kohler. 2005. Narrative Analysis. In Narrative, Memory \& Everyday Life. Huddersfield: University of Huddersfield, p. 17.

Robinson-Edwards, Shona. 2017. O.J. Simpson: 'I've Done My Time'—Religion, Remorse and Responsibility? Birmingham City University. Available online: http://blogs.bcu.ac.uk/views/2017/07/25/o-j-simpson-ivedone-my-time-religion-remorse-and-responsibility (accessed on 31 July 2017).

Robinson-Edwards, Shona, and Craig Pinkney. 2018. Black men, religiosity and desistance: Exploring Islam, desistance and identity. Safer Communities 17: 47-67. [CrossRef]

Ronel, Nattie, and Ben Yair. 2017. Spiritual Criminology: The Case of Jewish Criminology. International Journal of Offender Therapy and Comparative Criminology. [CrossRef] [PubMed]

Schmidt, Stefan. 2011. Mindfulness in East and West-Is it the Same? In Neuroscience, Consciousness and Spirituality. Edited by Harald Walach, Stefan Schmidt and Wayne B. Jonas. New York: Springer, pp. 23-38.

Schroeder, Ryan, and John Frana. 2009. Spirituality and Religion, Emotional Coping, and Criminal Desistance: A Qualitative Study of Men Undergoing Change. Sociological Spectrum: Mid-South Sociological Association 29: 718-41. [CrossRef]

Sedikides, Constantine, and Jochen E Gebauer. 2010. Religiosity as self-enhancement: a meta-analysis of the relation between socially desirable responding and religiosity. Personality and Social Psychology Review 14: 17-36. [CrossRef] [PubMed]

Sheldrake, Philip. 2012. Spirituality: A Very Short Introduction. Oxford: Oxford University Press.

Sumter, Melvina, and Todd Clear. 1998. An Empirical Analysis of Literature Examining the Relationship between Religiosity and Deviance since 1985. Tallahassee: Florida State University, unpublished manuscript.

Tart, Charles. 2012. The End of Materialism: How Evidence of the Paranormal is Bringing Science and Spirit Together. Oakland: New Harbinger Publications Inc.

The Mothers Union. 2007. Available online: http:/ / www.themothersunion.org/joinmothersunion.aspx (accessed on 10 December 2015). 
Thomas, Jim, and Barbara H. Zaitzow. 2006. Conning or conversion? The role of religion in prison coping. The Prison Journal 86: 242-59. [CrossRef]

Thornton, Lucy. 2016. 'Most Hated Mum in Britain' Karen Matthews Begs for Forgiveness after Faking Daughter Shannon's Kidnap. Available online: http:/ / www.mirror.co.uk/news/uk-news/mosthated-mum-britainkaren-9439985 (accessed on 3 January 2017).

Tomczak, Phillipa. 2017. The Penal Voluntary Sector. Abingdon: Routledge.

VanVleet, Russel, Jeff Cockayne, and Timothy Fowles. 1999. Examining Religion as a Preventative Factor to Delinquency. Religion and Delinquency. Available online: https://justice.utah.gov/Documents/Research/ Juvenile/Religion.pdf (accessed on 10 April 2018).

Wainwright, Martin. 2009. Shannon Matthews Kidnap: Mother Jailed for Eight Years. The Guardian. Available online: https:/ / www.theguardian.com/uk/2009/jan/23/shannon-matthews-mother-jail (accessed on 23 January 2018).

Wallis, Roy. 1976. The Road to Total Freedom. London: Heinemann.

Ward, Tony. 2002. Good Lives and the Rehabilitation of Offenders: Promises and Problems. Aggression and Violent Behavior 7: 513-28. [CrossRef]

Ward, Tony, and Shadd Maruna. 2007. Rehabilitation, Beyond the Risk Paradigm. Oxon: Routledge.

Weaver, Beth. 2015. Offending and Desistance: The Importance of Social Relations. London: Routledge.

Whitehead, Tom. 2010. Prisoners Converting to Islam for 'Perks'. Available online: http:/ /www.telegraph.co. uk/news/uknews/law-and-order/7808783/Prisoners-converting-to-Islam-for-perks.html (accessed on 24 April 2017).

Wilson, Robin, Janice Picheca, and Michelle Prinzo. 2005. Circles of Support and Accountability: An Evaluation of the Pilot Project in South-Central Ontario. Ottawa: Correctional Service of Canada, Available online: http:/ / www.csc-scc.gc.ca/research/092/r168_e.pdf (accessed on 10 April 2015).

Wolbrecht, Christina, Karen Beckwith, and Lisa Baldez. 2008. Political Women and American Democracy. New York: Cambridge University Press.

Yardley, Elizabeth, David Wilson, Dianne Kemp, and Michael Brookes. 2015. Narrative beyond Prison Gates: Contradiction, Complexity, and Reconciliation. International Journal of Offender Therapy and Comparative Criminology 59: 159-79. [CrossRef] [PubMed]

(C) 2018 by the authors. Licensee MDPI, Basel, Switzerland. This article is an open access article distributed under the terms and conditions of the Creative Commons Attribution (CC BY) license (http:/ / creativecommons.org/licenses/by/4.0/). 